\title{
TOXICITY OF THE ORGANIC EXTRACT FROM Annona muricata L. (ANNONACEAE) SEEDS ON Brevicoryne brassicae (L.) (HEMIPTERA: APHIDIDAE) IN CABBAGE CULTIVATION (Brassica oleracea L.)
}

\author{
Luan Carlos da Paz'; Ariane Morgana Leal Soares; Raiza Rocha Oliveira Teixeira²; José Pedro da Silva; Caio \\ Henrique Loureiro de Hollanda Ferreira3; Roseane Cristina Predes Trindade ${ }^{4}$
}

\begin{abstract}
1Doutorando em Proteção de Plantas, Centro de Ciências Agrárias (CECA), Universidade Federal de Alagoas (UFAL), BR 104 Norte, Km 85, Rio Largo, AL. CEP 57.000-100.

${ }^{2}$ Doutorando em Agriculture, Food and Environment, Dipartamento di Scienze Agrarie, Alimentari e Agro-ambientali, Università di Pisa, Via del Borghetto 80, Pisa, IT. 56124.

${ }^{3}$ Mestre em Agronomia, Centro de Ciências Agrárias (CECA), Universidade Federal de Alagoas (UFAL), BR 104 Norte, Km 85, Rio Largo, AL. CEP 57.000-100.

4Professora, Centro de Ciências Agrárias (CECA), Universidade Federal de Alagoas (UFAL), BR 104 Norte, Km 85, Rio Largo, AL. CEP 57.000-100.

Autor para correspondência: Luan Carlos da Paz, luancpaz@hotmail.com.
\end{abstract}

\begin{abstract}
The aim of this work was to evaluate the toxicity of extracts produced from dried Annona muricata seeds on Brevicoryne brassicae in cabbage (Brassica oleracea) cultivation. Three treatments were used: water plus ${ }^{\circledR D}$ Decis $25 \mathrm{EC}$ insecticide, water plus hexanic extract and water plus ethanolic extract, both extracts from A. muricata and one control: water plus adjuvant (®Tween 80 ). The mortality of B. brassicae was evaluated after 2 and $24 \mathrm{~h}$ after spraying. Tests were carried out in 3 ways: spraying in direct contact with the insect, spraying on natural surface (cabbage leaf) and spraying on artificial surface (paper). Five insects were used in each Petri dish, with 6 replicates per treatment in a factorial scheme 4 (treatments + control) $x 2$ (times). There was no statistical difference between extracts and the commercial chemical product for insecticidal action to $\mathrm{B}$. brassicae on cabbage plants.
\end{abstract}

KEYWORDS: Alternative Control, Soursop, Aphids

\section{TOXICIDADE DO EXTRATO ORGÂNICO DE SEMENTES DE Annona muricata L. (ANNONACEAE) SOBRE Brevicoryne brassicae (L.) (HEMIPTERA: APHIDIDAE) EM COUVE (Brassica oleracea L.)}

RESUMO: O trabalho teve como objetivo avaliar a toxicidade dos extratos produzidos a partir de sementes secas de Annona muricata sobre Brevicoryne brassicae no cultivo de couve (Brassica oleracea). Foram utilizados três tratamentos: água com inseticida ${ }^{\circledR} D e c i s ~ 25 \mathrm{EC}$, água acrescida de extrato hexânico e água acrescida de extrato etanólico, ambos de Annona muricata e uma testemunha: água acrescida de adjuvante (®Tween 80). Avaliou-se a mortalidade de Brevicoryne brassicae após 2 e $24 \mathrm{~h}$ após a pulverização. Os testes foram realizados de 3 formas: pulverização em contato direto com o inseto, pulverização em superfície natural (folha de couve) e pulverização em superfície artificial (papel). Foram utilizados 5 insetos em cada placa de Petri, com 6 repetições por tratamento, num esquema fatorial 4 (tratamentos + testemunha) x 2 (tempos). Não houve uma diferença estatística entre os extratos e o produto químico comercial para ação inseticida a Brevicoryne brassicae em plantas de couve (Brassica oleracea L.).

PALAVRAS-CHAVE: Contole Alternativo, Graviola, Afídios

\section{INTRODUCTION}

Plants belonging to family Brassicaceae are vegetables grown worldwide and of great economic importance in Brazil. Despite the well-defined botanical characteristics, cauliflower, cabbage, broccoli, Brussels sprouts, kohlrabi and borecole are botanical varieties of the same species (Brassica oleracea) and present common phytosanitary vulnerabilities (Brandão Filho et al., 2010; Liu et al., 2014).

Brassicas are host to a large number of pests, including cabbage aphid Brevicoryne brassica (L.) (Hemiptera: Aphididae), and are distributed in temperate 
and subtropical regions (Ahmad and Akhtar, 2013). In Brazil, the importance of $B$. brassicae as pest has been increasing due to the intensification of the brassica production, the increasing demand for good quality products and the difficulties to obtain adequate control of this insect in several crops (Minas et al., 2013). In addition, the insect may be a vector of the turnip mosaic virus, which also attacks several brassicas (Souza-Silva and Ilharco, 2008), which justifies its control.

Insecticidal plants are sources of bioactive substances compatible with Integrated Pest Management programs, being a strong ally to other insect control methods, maintaining the environmental balance, without leaving chemical residues (Torres et al., 2006). These plant-origin products are known to have insecticidal and inhibitory properties to a range of pest insects. The insect is attracted or repelled to feed by various chemical compounds in plants, called phytochemicals. These act as repellents, insecticides, growth inhibitors, ovicides and oviposition inhibitors. These compounds at different concentrations induce different modes of action in insects (Manickham et al., 2014).

Soursop tree Annona muricata L. is among plants used for alternative control, belonging to family Annonaceae and presenting compounds known as "Annonaceous acetogenins", substances responsible for the insecticidal action, as well as a range of important biological activities that can be found in different plant parts, especially seeds. In A. muricata, approximately 100 acetogenins have been identified (Bermejo et al., 2005; Castillo-Sánchez et al., 2010; Moghadamtousi et al., 2015).

Thus, the aim of this work was to evaluate the toxicity of extracts produced from dried $A$. muricata seeds on $B$. brassicae in cabbage cultivation ( $B$. oleracea).

\section{MATERIAL AND METHODS}

Experiments were carried out at the Laboratory of Entomology: Alternative Pest Control of the Agricultural Sciences Center - Federal University of Alagoas - CECA / UFAL, in Rio Largo - AL.

\section{Obtaining the study material}

Cabbage plants were grown in the CECA / UFAL campus for laboratory tests. B. brassicae aphids were obtained from plants infested in the cabbage crop, using only the most robust females in a young form, according to laboratory procedures.

\section{Obtaining seeds and preparation of extracts}

A. muricata seeds were collected in a fruit pulp plant in Anadia - AL. After removal of pulp residues from seeds, they were placed in kraft paper bags and dried in an oven with circulation of air at $50^{\circ} \mathrm{C}$ for seven days. Then, they were ground in a Wiley-type knife mill to obtain the powder, which was stored in tightly sealed glass containers until extracts were prepared. A plant exsicata was deposited in the herbarium of the Environmental Institute of Alagoas (IMA), in Maceió $A L$, under number MAC 34903. 44.

Extracts were prepared in the Laboratory of Research of Natural Resources (UFAL), according to methodology of Maciel etal. (2015). For organic extracts, $6 \mathrm{~kg}$ of seed powder were used, being submitted to cold extraction in stainless steel percolator, first with hexane [CH3(CH2)4CH3] (8 liters), for 24 hours, then on the cake resulting from extraction, ethanol $(\mathrm{CH} 3 \mathrm{CH} 2 \mathrm{OH})$ was added for cold extraction three times for 72 hours. In the first, second and third extractions, 6.0; 6.6 and 5.0 liters of ethanol were used, respectively. The material was filtered and then concentrated in a rotary evaporator at $50^{\circ} \mathrm{C}$ under reduced pressure. The same procedure was used for hexanic extract.

\section{Toxicity of Brevicoryne brassicae extracts on cabbage}

For tests, organic soursop (A. muricata) extracts (hexanic and ethanolic) at 3\% concentration, commercial insecticide Decis® $25 \mathrm{EC}$ at the dosage of $200 \mathrm{~mL} /$ ha were used; water was used to solubilize the products and, Tween 80 emulsifier (0.05\%) was used in all treatments. Water and Tween $® 80$ solution $(0.05 \%)$ was used as control.

Spraying was carried out using three different methods: directly on the insect, in this method, products had direct contact with aphids, by hand sprayer, taking care that all the insects were sprayed together; on a natural surface, leaf disks (arenas) of $7.0 \mathrm{~cm}$ in diameter were made with healthy cabbage leaves, which were sprayed with products using hand sprayer to the runoff point of the liquid on the leaf, from this moment, leaves were left to dry at room temperature to be placed on 
paper towel and then transferred to Petri dish $(8.5 \mathrm{~cm}$ in diameter); and on artificial surface to test the products with sprays in paper arenas of the same diameter of that used in natural surface, also left to dry, packaged in Petri dishes. In each Petri dish, 5 insects were released, which were sealed with plastic films to avoid insect escape from the treated area, in a total of 6 replicates per treatment.

Aphid mortality was evaluated 2 and 24 hours after spray applications, being considered dead when they could not move and did not respond to any external stimuli.

The mean number of dead insects per treatment was transformed into $\sqrt{ }(x+0.5)$, submitted to analysis of variance and the means compared by the Tukey test, at $5 \%$ probability, applying the factorial scheme $(4 \times 2)$, using the Sisvar software.

\section{RESULTS AND DISCUSSION}

When extracts were directly applied to insects, it was possible to observe that after two hours of application, no significant statistical difference was observed between the application of chemical insecticide and the ethanolic and hexanic soursop extracts, and there was also no difference between control and the hexanic extract. The same result could be observed 24 hours after the topical application of products. There was an evolution in the number of individuals killed over time, but without significant difference between periods after application (Table 1).

Table 1. Evaluation of products directly applied to Brevicoryne brassicae insects, two and 24 hours after application. Rio Largo, AL. 2017.

\begin{tabular}{ccc}
\hline & \multicolumn{3}{c}{ Topical Application } \\
\cline { 2 - 3 } & 2 hours & 24 hours \\
\hline Control & $0.70 \mathrm{bB}$ & $0.70 \mathrm{bB}$ \\
\hline Chemical Insecticide & $2.03 \mathrm{aA}$ & $2.19 \mathrm{aA}$ \\
\hline Hexanic extract & $1.47 \mathrm{baA}$ & $2.19 \mathrm{aA}$ \\
\hline Ethanolic Extract & $1.82 \mathrm{aA}$ & $2.27 \mathrm{aA}$ \\
\hline CV $(\%)$ & & \\
\hline
\end{tabular}

Means followed by the same lowercase letter in the columns and upper case in the row do not differ by the Tukey's test $(P \leq 0.05)$. Due to the transformation of data, control presents value other than $0 . C V=$ coefficient variation

Due to the lack of statistical difference for the commercial product compared to the extracts, it is possible to infer that $A$. muricata extracts are efficient in the control of $\mathrm{B}$. brassicae when spray is accurately applied on insects; however, at field level, it is very difficult to achieve this effect due to environmental factors and also to the insect behavior.

When the product was applied to evaluate the effects of ingestion on pulverized leaves (natural surface) and evaluated after 2 and 24 hours, data presented great variation as observed in table 2.

Table 2. Evaluation of products applied on cabbage leaves (natural surface) for ingestion of Brevicoryne brassicae insects, two and 24 hours after application. Rio Largo, AL. 2017.

\begin{tabular}{ccc}
\hline & \multicolumn{2}{c}{ Application on natural surface } \\
\cline { 2 - 3 } & 2 hours & 24 hours \\
\hline Control & $0.70 \mathrm{bB}$ & $0.70 \mathrm{cC}$ \\
\hline Chemical Insecticide & $0.70 \mathrm{bB}$ & $1.69 \mathrm{abAB}$ \\
\hline Hexanic extract & $1.34 \mathrm{aA}$ & $2.10 \mathrm{aA}$ \\
\hline Ethanolic Extract & $0.79 \mathrm{bB}$ & $1.22 \mathrm{bcB}$ \\
\hline CV. (\%) & & \\
\hline
\end{tabular}

Means followed by the same lower case letter in the columns and upper case in the row do not differ by the Tukey's test $(P \leq 0.05)$. Due to the transformation of data, control presents value other than $0 . C V=$ coefficient variation 
In this evaluation, the hexanic extract was more efficient than the other treatments and the control, and presented a greater number of dead individuals after two hours of application. After 24 hours of application, there was an increase in mortality, and the hexanic extract had the highest absolute mortality rate, but without statistical difference from the commercial chemical. Control treatment presented no dead insects. A difference between the time elapsed after the application and the product was observed, the hexanic extract being considered as efficient under these conditions as the commercial product, regardless of time factor.

The results obtained in this evaluation are different from those observed in the work of Trindade et al. (2000), who reported that the efficiency differences of extracts vary according to the solvents used, and it was observed that the best results were obtained using the ethanolic extract. Extracts produced using hexanic solvent are less efficient than those with intermediate polarity such as organic solvent (Ethanolic) (Trindade et al., 2018).

The residual evaluation two hours after the application did not present statistical difference among treatments, although the hexanic extract presented the best absolute mortality in the evaluation period. In the 24 hours after application, there was also no difference among treatments and the chemical insecticide and hexanic extract residue presented the best results, but without statistical difference between these treatments and the ethanolic extract. In relation to the evaluated times, there was no significant difference within treatments (Table 3).

Table 3. Residual analysis evaluation (artificial surface) of products applied to control Brevicoryne brassicae, two and 24 hours after application. Rio Largo, AL. 2017.

\begin{tabular}{ccc}
\hline & \multicolumn{2}{c}{ Application on artificial surface } \\
\cline { 2 - 3 } & 2 hours & 24 hours \\
\hline Control & $0.70 \mathrm{bB}$ & $0.70 \mathrm{bB}$ \\
\hline Chemical Insecticide & $1.03 \mathrm{abAB}$ & $1.32 \mathrm{aA}$ \\
\hline Hexanic extract & $1.14 \mathrm{abA}$ & $1.26 \mathrm{aA}$ \\
\hline Ethanolic Extract & $0.88 \mathrm{abAB}$ & $1.05 \mathrm{abAB}$ \\
\hline CV. (\%) & & \\
\hline
\end{tabular}

Means followed by the same lowercase letter in the columns and upper case in the row do not differ by the Tukey's test $(\mathrm{P} \leq 0.05)$. Due to the transformation of data. control presents value other than $0 . \mathrm{CV}=$ coefficient variation

Plant extracts are more commonly used in works that evaluate the insecticidal capacity for knowing their toxicity action and for concentrating most of the active principles in relation to other plant parts (Rodriguez, 2000).

Species of the genus Annona are evidenced in researches due to their high insecticidal potential on insects of different orders and mites, as found by Ribeiro et al. (2014) in Trichoplusia ni (Hubner) (Lepidoptera: Noctuidae) and Myzus persicae (Theobald) (Hemiptera: Aphididae), for Aedes albopictus (Skuse, 1894) (Diptera: Culicidae) and Culex quinquefasciatus Say (Diptera: Culicidae) (Ravaomanarivo et al., 2014). Carvalho et al. (2008) and Maciel et al. (2015) reported the efficiency of the application of Annona extracts in various species of mites.

A. muricata extracts were efficient in controlling Plutella xylostella (L.) larvae and pupa (Lepidoptera:
Plutellidae) also in B. oleracea (Trindade et al., 2011) and it was observed that the hexanic A. muricata extract was efficient in the control of Sitophilus zeamais (Motschulsky) (Coleoptera: Curculionidae) (Llanos et al., 2008). The use of extracts obtained from $A$. mucosa leaves and seeds can satisfactorily control Euschistus heros (F.) (Hemiptera: Pentatomidae), especially the extract obtained from seeds (Turchen et al., 2016).

In addition to efficiency, these studies emphasize the importance of the use of $A$. muricata extract for sustainable agricultural production that seeks alternatives for the control of pests with minimum contamination to environment, humans and animals. Some plant extracts can be integrated with strategies of integrated pest management, since they can be selective to natural enemies, as is the case of the extract obtained from A. crassiflora, which was 
selective to parasitoid Trissolcus urichi Crawford, 1913 (Hymenoptera: Platygastridae) (Turchen et al., 2014).

According to the results of this work, the hexanic extract from $A$. muricata seeds showed better insecticidal action against $B$. brassicae in cabbage plants (B. oleracea), similar to the commercial chemical. In this way, it could be inferred that it is a natural product with insecticidal potential that can be used in the integrated pest management of cabbage crop and further research can be developed to evaluate its viability of control and use in agriculture in general.

\section{REFERENCES}

Ahmad, M.; Akhtar, S. Development of insecticide resistance in field populations of Brevicoryne brassicae (Hemiptera: Aphididae) in Pakistan. Journal of Economic Entomology. 2013, 106, 2, 954-958.

Bermejo, A.; Figadere, B.; Zafra-Polo, M.C.; Barrachina, I.; Estornell, E.; Cortes, D. Acetogenins from Annonaceae: recent progress in isolation, synthesis and mechanisms of action. Natural Product Reports. 2005, 22, 2, 269-303.

Brandão Filho J.U.T.; Santos, H.S.; Maraus, P.F.; Santos, S.S. Controle químico da traça das crucíferas (Plutella xylostella) na cultura do repolho. Horticultura Brasileira. 2010, 28, 795-800.

Carvalho, T.M.B.; Reis, P.R.; Oliveira, D.F.; Carvalho, G.A.; Carvalho, D.A. Avaliação de extratos vegetais no controle de Oligonychus ilicis (McGregor, 1917) (Acari: Tetranychidae) em laboratório. Coffee Science. 2008, 3, 2, 94-103.

Castillo-Sánchez, L.H.C.; Jiménez-Osornio, J.J.; Delgado-Herrera, M.A. Secondary metabolites of the Annonaceae, Solanaceae and Meliaceae families used as biological control of insects. Tropical and Subtropical Agroecosystems. 2010, 12, 3, 445-462.

Llanos, C.A.H.; Arango, D.L.; Giraldo, M.C. Actividad insecticida de extractos de semilla de Annona muricata (Anonaceae) sobre Sitophilus zeamais (Coleoptera: Curculionidae). Revista Colombiana de Entomologia. 2008, 34, 1, 76-82.
Liu, S.; Liu, Y.; Yang, X.; Tong, C.; Edwards, D.; Parkin, I.A.P.; Zhao, M.; Ma, J.; Yu, J.; Huang, S.; Wang, X.; Wang, J.; Lu, K.; Fang, Z.; Bancroft, I.; Yang, T.; Hu, Q.; Wang, X.; Yue, Z.; Li, H.; Yang, L.; Wu, J.; Zhou, Q.; Wang, W.; King, G.J.; Pires, J.C.; Lu, C.; ZhangyanWu; Sampath, P.; ZhuoWang; Guo, H.; Pan, S.; Yang, L.; Min, J.; Zhang, D.; Jin, D.; Li, W.; Belcram, H.; Tu, J.; Guan, M.; Qi, C.; Du, D.; Li, J.; Jiang, L.; Batley, J.; Sharpe, A.G.; Park, B.; Ruperao, P.; Cheng, F.; Waminal, N.E.; Huang, Y.; Dong, C.; LiWang; Li, J.; Hu, Z.; Zhuang, M.; Huang, Y.; Huang, J.; Shi, J.; Mei, D.; Liu, J.; Lee, T.; Wang, J.; Jin, H.; Li, Z.; Li, X.; Zhang, J.; Xiao, L.; Zhou, Y.; Liu, Z.; Liu, X.; Qin, R.; Tang, X.; Liu, W.; YupengWang; Zhang, Y.; Lee, J.; Kim, H.H.; Denoeud, F.; Xu, X.; Liang, X.; Hua, W.; Wang, X.; Wang, J.; Chalhoub, B.; Paterson, A.H. The Brassica oleracea genome reveals the asymmetrical evolution of polyploid genomes. Nature communications. 2014, 5, 1-11.

Maciel, A.G.; Rodrigues, J.S.; Trindade, R.C.P.; Silva, E.S.; Sant'Ana, A.E.G.; Lemos, E.E. Effect of Annona muricata L. (1753) (Annonaceae) seeds extracts on Tetranychus urticae (Koch, 1836) (Acari: Tetranychidae). African Journal of Agricultural Research. $2015,10,48,4370-4375$.

Manickham, A.; Kathirvelu, B.; Sundaram, J.; Munusamy, A. Bio-efficacy of crude leaf extracts of Acalypha fruticosa Forssk against some agriculturally important insect pests. Asian Pacific Journal of Tropical Disease. 2014, 4, S890-S894.

Minas, R. S.; Rondelli, V. M.; Melo, D. F.; Oliveira, C. M. R.; Bestete, L. R. Solanáceas: abordagem das principais culturas e suas pragas. Kiron: Brasília, 2013, 268.

Moghadamtousi, S.Z.; Fadaeinasab, M.; Nikzad, S.; Mohan, G.; Ali, H.M.; Kadir, H.A. Annona muricata (Annonaceae): a review of its traditional uses, isolated acetogenins and biological activities. International journal of molecular sciences. 2015, 16, 7, 1562515658.

Ravaomanarivo, L.H.R.; Razafindraleva, H.A.; Raharimalala, F.N.; Rasoahantaveloniaina, B.; Ravelonandro, P.H.; Mavingui, P. Efficacy of seed extracts of Annona squamosa and Annona muricata 
(Annonaceae) for the control of Aedes albopictus and Culex quinquefasciatus (Culicidae). Asian Pacific Journal of Tropical Biomedicine. 2014, 4, 10, 798-806.

Ribeiro, L.P.; Akhtar, Y.; Vendramim, J.D.; Isman, M.B. Comparative bioactivity of selected seed extracts from Brazilian Annona species and an acetogenin-based commercial bioinsecticide against Trichoplusia ni and Myzus persicae. Crop Protection. 2014, 62, 100-106.

Rodríguez, H. C. Plantas contra plagas: potencial práctico de ajo, anona, nim, chile y tabaco. Texcoco: Red de Acción sobre Plaguicidas y Alternativas en México (RAPAM). 2000

Souza-Silva, C. R.; Ilharco, F. A. Afídeos (Hemiptera: Aphididae) das couves. Revista de agricultura. 2008, 83, 87-91.

Torres, A.L.; Junior, A.L.B.; Medeiros, C.A.M.; Barros, R. Efeito de extratos aquosos de Azadirachta indica, Melia azedarach e Aspidosperma pyrifolium no desenvolvimento e oviposição de Plutella xylostella. Bragantia, 2006, 65, 3, 447-457.
Trindade, R. C. P.; Marques, I. M. R.; Xavier, H. S.; Oliveira, J.D. Extrato metanólico da amêndoa da semente de nim e a mortalidade de ovos e lagartas da traça-do-tomateiro. Scientia Agricola. 2000, 57, 3, 407413.

Trindade, R.C.P.; Luna, J.S.; Lima, M.R.F.; Silva, P.P.; Sant ana, A.E.G. Larvicidal activity and seasonal variation of Annona muricata (Annonaceae) extract on Plutella xylostella (Lepidoptera: Plutellidae). Revista Colombiana de Entomologia. 2011, 37, 2, 223-227.

Trindade, R.C.P.; Gomes, I.B.; Lemos, E.E.P.; Sant'Ana, A.E.G. Toxicity of soursop extracts to diamondback moth. Bioscience Journal. 2018. 34, 1, 104-111.

Turchen, L.M.; Golin, V.; Butnariu, A.R.; Pereira, M.J.B. Selectivity of Annona (Annonaceae) extract on egg parasitoid Trissolcus urichi (Hymenoptera: Platygastridae). Revista Colombiana de Entomología. 2014, 40, 2, 176-180.

Turchen, L.M.; Hunhoff, L.M.; Paulo, M.V.; Souza, C.P.R.; Pereira, M.J.B. Potential phytoinsecticide of Annona mucosa (Jacq)(Annonaceae) in the control of brown stink bug. Bioscience Journal. 2016, 32, 3, 581587. 